Synthesis, part of a Special Feature on Ecological Restoration in Northern Regions

\title{
Shifting Restoration Policy to Address Landscape Change, Novel Ecosystems, and Monitoring
}

\author{
Joy B. Zedler ${ }^{1}$, James M. Doherty ${ }^{1}$ and Nicholas A. Miller ${ }^{2}$
}

\begin{abstract}
Policy to guide ecological restoration needs to aim toward minimizing the causes of ecosystem degradation; where causes cannot be eliminated or minimized, policy needs to shift toward accommodating irreversible landscape alterations brought about by climate change, nitrogen deposition, altered hydrology, degraded soil, and declining biodiversity. The degree to which lost diversity and ecosystem services can be recovered depends on the extent and nature of landscape change. For wetlands that occur at the base of watersheds that have been developed for agriculture or urban centers, the inflows of excess water, sediment, and nutrients can be permanent and can severely challenge efforts to restore historical services, including biodiversity support. In such cases, the historical state of downstream wetlands will not be completely restorable. Wetland restoration policy should promote watershed planning, wherein wetland and upland restoration is prioritized to achieve multiple, specific ecosystem services. For downstream wetlands, it is realistic to aim to enhance nitrogen removal and to establish native plants that are matrix dominants, namely, those that facilitate rather than displace other natives. More ambitious objectives such as maximizing diversity would be suitable for less-altered, upstream wetlands. Policy should also call for adaptive restoration and long-term assessments. For large sites and multiple sites of a given wetland type within a region, experimental tests can determine a wetland's ability to support high levels of ecosystem services. Once projects are underway, long-term monitoring of structural and functional indicators can characterize progress toward each objective. Managers can then learn which targets are unachievable based on data, not just opinion. Where an experimental treatment shows limited progress, practitioners would shift to more promising treatments and targets, thereby adapting restoration efforts to changing landscapes. Rather than ensuring duplication of historical conditions, an adaptive restoration framework allows practitioners to aim high while using field tests to identify unachievable targets and adapt ecological restoration to landscape change.
\end{abstract}

Key Words: adaptive restoration; conservation of biodiversity; ecological restoration; ecosystem services; landscape alteration; watershed plan; wetland

\section{INTRODUCTION}

Landscape changes follow from human development (Fig. 1), agriculture, river diversions, and impoundments, activities that appear to be irreversible. Landscapes also change from the indirect effects of our growing population, which leads to climate change, deposition of air-borne materials, and losses in biodiversity (Millennium Ecosystem Assessment 2005). Landscapes experience even greater change when local conditions interact with climatic factors to cause catastrophes, e.g., a wetland that is downstream from a highly modified watershed suddenly experiences frequent flooding and sedimentation, and its biodiversity drops precipitously (Zedler 2010a). Where direct human impacts are most severe, as during open-pit or strip mining, neither the native biota nor the natural substrate remains. Even where impacts are less severe, such as during the invasion of an aggressive plant species, ecosystems tend to lose biodiversity (Stohlgren et al. 2011).

Although restoration to earlier, less-degraded conditions is often an ideal goal, the historical state is not always attainable given irreversible changes in abiotic conditions and available biota (Pickett and Parker 1994, Harris et al. 2006, Hobbs et al. 2011). Common constraints are the alterations in landscape settings, disturbance regimes, invasive species, declining biodiversity, hydrological regime, habitat type, soil properties, topography, nutrient supplies, depleted seed banks, climate change, and deposition of nitrogen and dust (Zedler 2000, Harris et al. 2006, Galloway et al. 2008, Prospero et al. 2012). Future research might solve some restoration problems that seem unsolvable today; in the meantime, it is practical to be realistic and acknowledge that many ecosystems and restoration sites are novel, often having fewer native species and more exotic species, which in turn modify ecosystem processes. A novel ecosystem might be more sustainable than a site that requires continual remodeling in an attempt to achieve the unachievable.

Despite heightened awareness of changed landscapes, few scientists go beyond listing problems to clarifying how policies could be changed to improve restoration (Suding 2011). In a recent meta-analysis of papers about restoration in 13 journals, fewer than $10 \%$ of 1582 papers referred to policy, and almost none made recommendations to improve policy (Aronson et al. 2010). Tischew et al. (2010:477) recommend "planning, implementation, as well as monitoring of goal achievement, and follow-up management for maintaining target conditions of compensation measures" in their review 
Fig. 1. Seventy-one years of landscape change surrounding the University of Wisconsin-Madison Arboretum (1937, left; 2008, right). Images are from the U.S. Department of Agriculture, with the 2008 Arboretum boundary added by Mark Wegener, Arboretum Database Manager.

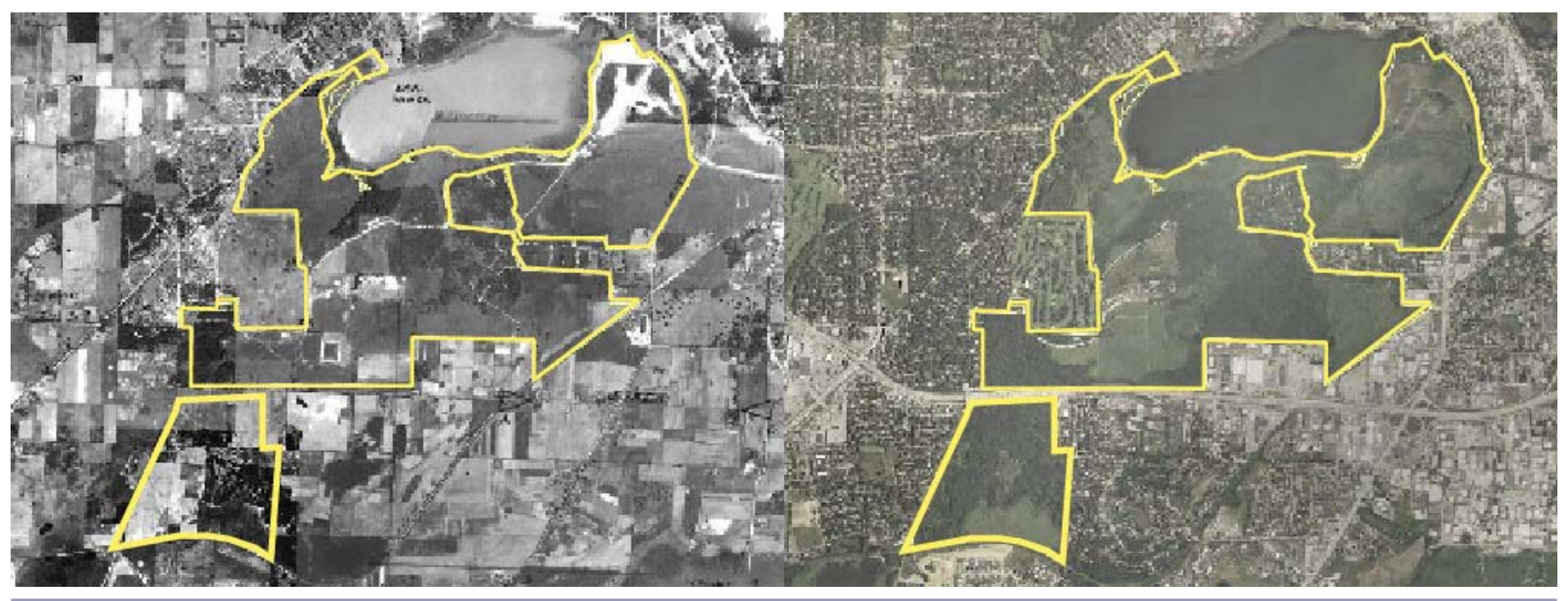

of 119 compensatory mitigation projects. Policy to mitigate the environmental impacts of proposed developments also needs to be strengthened (Environmental Law Institute and The Nature Conservancy, unpublished manuscript).

Current policy and public opinion guide planners to restore historical conditions, even for highly damaged ecosystems that cannot be fully restored (Seastedt et al. 2008, Hobbs et al. 2011). One approach is to select reference sites and expect restoration outcomes to fall within their range of conditions (Brinson 1993, Choi 2004, 2007, Suding 2011). A hidden assumption is that species that persist in reference sites can be reestablished under current conditions. Some species, however, established under different conditions decades ago and persist only through vegetative growth. At San Quintín Bay, Mexico, for example, the presence of an obligate salt marsh plant (Arthrocnemum suberminalis) on sandy dunes was unexplained until erosion exposed a tap root that extended several meters deep, into wet soil, indicating establishment in a salt marsh and persistence as sand accreted. If regeneration niches (Grubb 1977) cannot be recreated, restorationists should not expect to re-establish species that require historical conditions for germination and early growth.

Restoration policy also needs to emphasize appropriate assessments and objective judgments of progress, not just opinion. Like the restoration process, monitoring is a longterm commitment. Restoration takes decades in changing landscapes and is never finished (Moreno-Mateos et al. 2012). Because many restoration efforts are publicly funded and provide measurable benefits to society (Rey Benayas et al. 2009, Aronson et al. 2010), it is time for public agencies and non-governmental organizations (NGOs) to update ecological restoration targets and assessments to accommodate changing landscapes.

The audience for science-based restoration policy is large and includes all those who fund, regulate, manage, and judge restoration efforts. In the United States, wetland mitigation policy is developed by the U.S. Environmental Protection Agency (EPA) and U.S. Army Corps of Engineers, who judge compliance of projects in relation to initial requirements and issue periodic regulatory guidance letters. Wetland restoration on private land is funded by the U.S. Fish and Wildlife Service (FWS) in its Partners for Wildlife program, and by the U.S. Natural Resources Conservation Service in its Wetland Reserves Program, which is funded by the Farm Bill. Additional restoration work is accomplished by NGOs such as The Nature Conservancy (TNC) and Ducks Unlimited. The need for new national policy for wetlands is periodically addressed by the Environmental Law Institute (Environmental Law Institute and The Nature Conservancy, unpublished manuscript) and the National Research Council (e.g., National Research Council Committee on Wetland Mitigation 2001). Key Environmental Law Institute projects concern restoration and wetlands, especially mitigation banks and watershed planning.

Policy for adapting restoration targets to degraded landscapes should address global change, altered watersheds, degraded sites, and diminished species pools, any one of which can hinder efforts to reverse the decline of ecosystem services, including biodiversity support. Our recommendations follow from restoration research and experience in both coastal and 
inland landscapes, especially downstream wetlands (Zedler 2003, 2010a,b).

\section{LANDSCAPE CHANGE AND NOVEL ECOSYSTEMS}

\section{Addressing global change}

Escalating global change prompted Hobbs et al. (2011) to consider traditional restoration goals to be unachievable. Three global changes that especially challenge restoration efforts are increased frequency and intensity of storms, rapidly rising sea level, and increased quantity and mobility of nitrogen (Millennium Ecosystem Assessment 2005). These global stressors interact with one another and with other stressors, e.g., storms increase sediment accretion (Schuerch et al. 2012), sedimentation rates potentially exceed rates of coastal inundation, and storms mobilize nitrogen. In Iceland, volcanic ash deposits are widespread, especially from the volcano Hekla (Arnalds 2010). Meltwater flooding moves these deposits, producing large sediment plumes that dry and lead to regional dust storms (Prospero et al. 2012). A current aim is to ameliorate the winds and stabilize the soils by restoring native birch (Betula pubescens) and willow (Salix spp.) woodlands to $900-1000 \mathrm{~km}^{2}(\sim 1 \%)$ of Iceland. The most erodible substrates are stabilized by seeding grasses and fertilizing to accelerate growth, with trees added in clusters to allow expansion over time (Aradóttir 2007). Icelandic researchers are already experimenting with methods to reestablish native birch forests across $200 \mathrm{~km}^{2}$ (Halldórsson et al. 2011).

At Tijuana Estuary, California, the Pacific Decadal Oscillation led to insights into the impacts of extreme storms. Benign weather for $\sim 40 \mathrm{yr}$ allowed the salt marsh to become diverse, but the next $\sim 30 \mathrm{yr}$ of frequent extreme flooding led to sedimentation, which smothered several hectares of high marsh vegetation, elevated the marsh plain, and reduced diversity. Extreme flooding and sedimentation in 1983, followed by drought in 1984, extirpated short-lived plant species across most of the salt marsh (Zedler and West 2008, Zedler 2010a). Although Tijuana Estuary still has capacity for nutrient removal, wildlife support, and cultural services, the restoration of diverse salt marsh is no longer realistic. Restorationists instead aim to sustain tidal flushing while accepting a marsh plain dominated by pickleweed (Sarcocornia pacifica). Restoration policy should encourage planners to consider the impacts of extreme storms, floods, and droughts, plus sequence effects that might be catastrophic; envisioning such scenarios will make restoration targets more realistic. Extreme events have far greater impacts in the short term than gradual changes in temperature and rainfall.

Coastal wetlands are further threatened by a rapidly rising sea level. If sedimentation elevates the tidal marsh plain faster than the sea level rises, as at Tijuana Estuary, tidal influence is reduced, and salt marshes experience drier, more saline conditions. If sedimentation does not keep up with inundation, coastal wetlands drown. While it might seem impossible to adapt restoration to increased inundation, Europeans developed a policy of managed realignment and shifted wetland restoration efforts inland to compensate for more frequent inundation (drowning) of shoreline wetlands (ABP Marine Environmental Research, Ltd., Online managed realignment guide: http://www.abpmer.net/omreg/default. aspx). Great Britain, Germany, and the Netherlands are adapting to landscape change by restoring marshlands behind dikes.

Excess nutrients pose many constraints for restoration. Substantial increases in fertilizer production, partial fossil fuel combustion, dairy farms, livestock feedlots, and other human activities have enriched nitrogen globally via broad dispersal of gaseous ammonia and nitrogen oxides (Galloway et al. 2008, Jordan et al. 2011, Davidson et al. 2012). Where rural and urban surfaces are impervious, nitrogen moves downstream in runoff, accumulates in wetlands, and drives changes in vegetation. Nitrogen affects native plants directly and indirectly by enhancing distributions of aggressive weeds that displace native species (Bobbink et al. 2010, Stohlgren et al. 2011, Fox et al. 2012). In the United States, several invasive clonal graminoids expand vegetatively and displace desired native species (Drexler and Bedford 2002, Frieswyk et al. 2007). To counter increased nitrogen in agricultural watersheds of southwestern Sweden, the country began working toward a goal of adding 12,000 ha of shallow, vegetated wetlands (Helsinki Commission 2003, Arheimer et al. 2004, Hansson et al. 2005, Thiere et al. 2011).

The examples of large-scale forest restoration in Iceland, managed realignment along European shorelines, and wetland construction in Sweden all show that it is feasible to reduce the impacts of global stressors. While it is always good policy to address the causes of environmental degradation, it is still necessary to plan ahead for the stressors that cannot be removed. We recommend that restoration policy emphasize preparedness for changes in climate, sea level, and nitrogen loading (Table 1). Rather than aiming to turn back the clock in highly degraded sites, we also recommend that restorations begin as long-term experiments, aiming for historical targets and gradually ruling out those that can no longer be achieved. This adaptive approach (Zedler and Callaway 2003) requires the design and prioritization of experiments that will identify treatments that move the site toward desired outcomes. An initial phase might test for species and assemblages that can establish and persist (as in Lindig-Cisneros and Zedler 2002, Doherty et al. 2011); a second phase might test the benefits of adding topographic heterogeneity (as in Larkin et al. 2008, 2009). Then, managers would commit to a long-term process of assessing progress and responding to new knowledge, as discussed below. As assessments indicate the objectives that are unachievable, more realistic targets would be adopted and new experiments might begin. Adaptive restoration requires 
Table 1. Constraints on restoration of downstream wetlands, and recommended policies for landscape-change adaptation.

\begin{tabular}{lll}
\hline \hline Scale of constraints & Restoration challenge & Policy recommendations \\
\hline Globe & $\begin{array}{l}\text { Rapidly rising sea level, climate extremes, } \\
\text { nitrogen mobility }\end{array}$ & $\begin{array}{l}\text { Preparedness: predict future conditions; aim high but do not expect to } \\
\text { recreate historical levels of biodiversity and services; envision } \\
\text { alternative scenarios; field tests will indicate that some targets are } \\
\text { unachievable }\end{array}$ \\
Watershed & Excess water, eutrophication & $\begin{array}{l}\text { Create strategic watershed plans that identify watershed needs and then } \\
\text { prioritize restoration of potentially restorable sites and expected levels } \\
\text { of each service; track impacts in downstream wetlands; conserve or } \\
\text { restore diversity upstream; compare outflowing water from watersheds } \\
\pm \text { substantial restoration to assess effects of restoration }\end{array}$
\end{tabular}

Site $\quad$ Poor substrate, invaders

Biota $\quad$ Fewer species and smaller gene pools

Assessment needs Insufficient monitoring
Shift target from restoration of historical states to adaptive restoration; aim high but use field experiments to rule out targets that cannot be achieved

Retain and restore habitat for declining species where it occurred historically, where it might be achievable, near remnant populations, and in sites near one another; establish matrix dominants first, then test a site's ability to support diverse species and genotypes

Plan for clear and objective assessments; assess sites at intervals using objective indicators for abiotic and biotic components and services; set standards a priori; use data to judge progress at intervals, over long time periods a commitment to manage sites indefinitely, rather than anticipating an early outcome of self-sustainability.

\section{Addressing watershed change}

Because developed watersheds continue to discharge excess water of low quality, the need is to identify key places, areas, and types of wetlands to restore within a watershed framework (National Research Council Committee on Wetland Mitigation 2001). Policy should promote strategic watershed planning so that potentially restorable wetlands are prioritized for restoration according to their ability to enhance ecosystem services. Stakeholders would first identify watershed needs, i.e., attributes that would enhance watershed functioning. A framework would be based on maps and quantitative analysis of former wetlands, current wetlands, potentially restorable wetlands, and adjacent upland habitats. Ecosystem services would be estimated for each wetland and watershed so that historical losses and potential gains could be mapped.

The Conservation Foundation (1988) developed a policy of "no net loss" of wetlands, which became U.S. policy under President G. H. W. Bush. This led to compensatory mitigation, a policy that allows some loss of wetland area in exchange for restoration or creation of other wetlands. Rather than prevent damage to wetlands, impacts were to be compensated on-site with wetlands of a similar kind. However, a panel of experts (National Research Council Committee on Wetland Mitigation 2001) found numerous shortcomings in the implementation of this policy and recommended that wetland restoration follow watershed plans (although few existed at the time) so that watershed needs would be met in a more strategic manner than on-site, in-kind mitigation. Seven years later, U.S. regulatory agencies (EPA and U.S. Army Corps of Engineers) endorsed the recommendation and began providing guidance on how to comply in situations in which watershed plans were lacking.

Recent efforts in watershed planning for wetland restoration fall along a spectrum from a broadly based decision-making framework to prescribed outcomes for specific sites (reviewed in Environmental Law Institute and The Nature Conservancy, unpublished manuscript). In 2011, TNC volunteered to create three model watershed plans within Wisconsin, Georgia, and Tennessee. Technical experts in Wisconsin (Miller et al. 2012; Box 1) pulled together GIS data to identify potentially restorable wetlands and adjacent upland habitats to show where restoration could produce the greatest gains in seven ecosystem services.

Box 1: A model watershed plan for wetland restoration in the Great Lakes region.

A new policy, to use watershed planning approaches across the United States, was recommended by the National Research Council Committee on Wetland Mitigation (2001) but not endorsed by regulatory agencies until 2008. Then, the U.S. Environmental Protection Agency and U.S. Army Corps of Engineers defined a watershed approach as "an analytical process for making 
compensatory mitigation decisions that support the sustainability or improvement of aquatic resources in a watershed. It involves consideration of watershed needs, and how locations and types of compensatory mitigation projects address those needs" (Final Rule, 33 CFR 332.2/40 CFR 230.92). A recent review of existing watershed approaches revealed a broad spectrum ranging from site-based decision-making frameworks to highly analytical and prescriptive watershed plans (Environmental Law Institute and The Nature Conservancy, unpublished manuscript). In 2010, The Nature Conservancy began watershed planning in conjunction with key partners (local governments, regulatory agencies, nongovernmental organizations, and ecologists). Their approach falls in the middle of the spectrum: it aims to determine watershed needs and to identify opportunities for restoration to achieve those needs while maintaining flexibility for users to set priorities based on individual goals.

The approach of Miller et al. (2012) accomplishes four objectives: it creates a watershed profile to help users set goals and identify subwatersheds in which to focus conservation efforts (Fig. 2); it identifies places that have the greatest potential to provide an array of ecosystem services (Fig. 3); it emphasizes wetland-upland connections important to wildlife; and it aligns with State Wildlife Action Plans. The first step was to profile watershed needs by assessing historical losses in ecosystem services based on changes in the extent and condition of wetlands. Hydrogeomorphic features were used to predict the level of wetland service provision in sub-watersheds at two times, the early 1800 s and present day, by adapting methods developed by Adamus et al. (1991) and Tiner (2005). Relative losses were determined by sub-watershed for four ecosystem services: water quality improvement, surface water supply, flood abatement, and carbon sequestration. The resulting watershed profile can be used to set wetland service goals and to identify sub-watersheds that could yield the greatest returns in services (Fig. 2).

After determining watershed-scale needs, Miller et al. (2012) assessed the potential for individual sites (existing wetlands and potentially restorable wetlands) to provide multiple and individual ecosystem services, i.e., ability to abate flooding, improve water quality, supply surface water, protect shorelines, store carbon, and provide habitat for fish and wildlife (Fig. 3). Habitat services were established by the Wildlife Tool (Kline et al. 2006), which models areas likely to support target species based on known species requirements and field data on occurrences. Non-wildlife services were estimated based on opportunity (whether the site could provide the services), effectiveness (whether it would perform the service well), and significance (how much would people benefit). The resulting plan can be viewed interactively with other layers relevant to watershed restoration at http://maps.tnc.org/DuckPenTool.

As watersheds change, by conversion of open land to agriculture and of farms to urban land use, water quality will decline and downstream wetlands will be more threatened by invasive species and diversity loss. Adapting restoration efforts to achieve desired targets in developing watersheds involves the prioritization of sites where each ecosystem service can be replaced or mitigated. Such prioritization addresses landscape change and novel ecosystems.
Fig. 2. Relative losses in water quality protection since the 1800s due to wetland destruction and degradation in the three watersheds that compose the Duck-Pensaukee Basin, Wisconsin. Each color-ramp represents one of three watersheds in the basin. Results are reported by subwatershed, with darker shades indicating greater losses. Maps were also created for losses in surface water supply, flood abatement, and carbon sequestration. Map from Miller et al. (2012) using data from The Nature Conservancy, U.S. Fish and Wildlife Service, Wisconsin Department of Natural Resources, ESRI, and other partners.

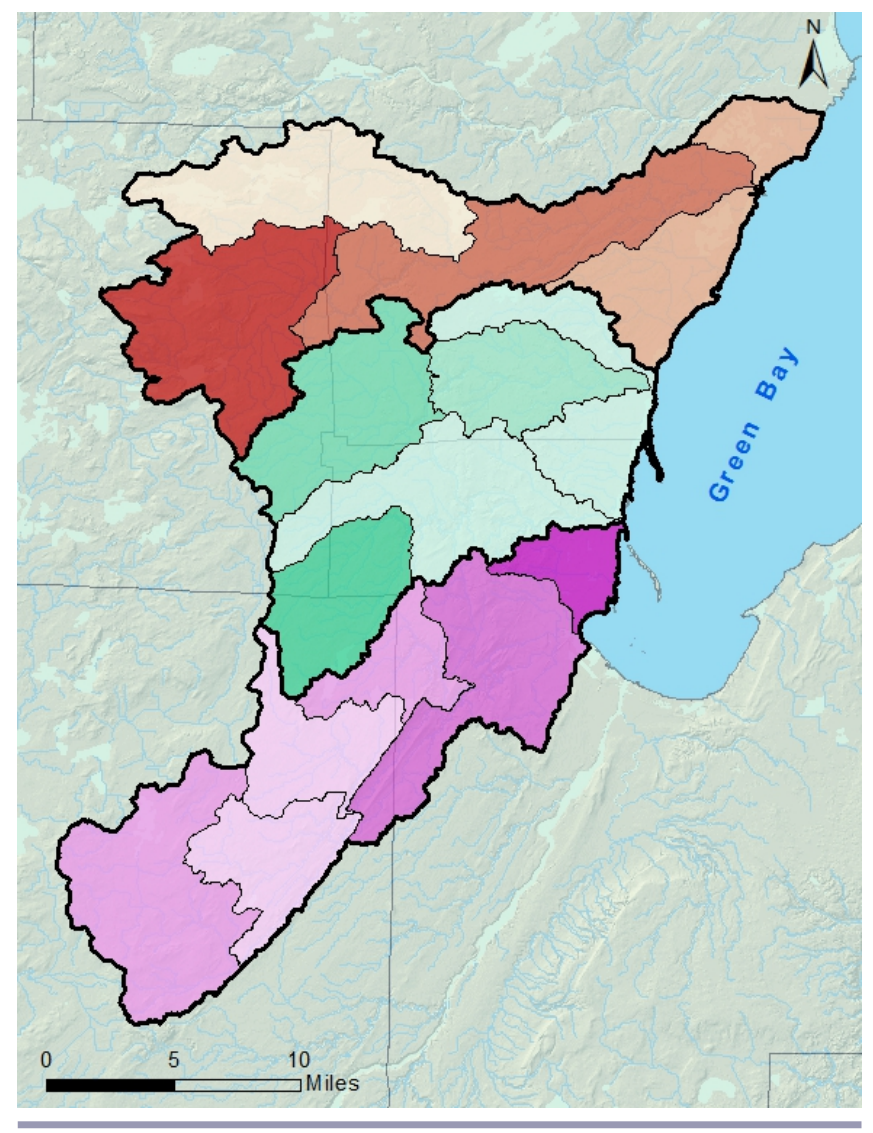

Watershed plans can also include an experimental component such as pairing watersheds with and without major restoration work and then sampling water quality at the watersheds' outflows. TNC initiated such a project in a 300,000-ha watershed of the Mackinaw River in central Illinois. Landowners in one watershed were encouraged to restore wetlands under the U.S. Conservation Reserve Program and to use green approaches such as planting winter cover crops to take up and hold nitrogen and phosphorus on the land. Water in streams became cleaner than in a paired watershed without green approaches (e.g., http://www.nature.org/ourinitiatives/ habitats/riverslakes/ 
placesweprotect/mississippi-river-priority-site-mackinaw-river. $\underline{\mathrm{xml}}$ and $\mathrm{http}: / / \mathrm{www}$.nature.org/ourinitiatives/regions/northamerica/ unitedstates/illinois/placesweprotect/the-mackinaw-river-watershed. xml). Sampling water for several years before and after restoration would improve statistical power (Schmitt and Osenberg 1996). Such potential exists for a large watershed complex along Wisconsin's Green Bay (Box 1).

Fig. 3. Potential for existing wetlands (green shades) and potentially restorable wetlands (red shades) to provide a suite of seven services, including flood abatement, water quality protection, surface water supply, shoreline protection, carbon sequestration, and fish and wildlife habitat. Darker shades indicate greater numbers of services provided at high levels. Map from Miller et al. (2012).

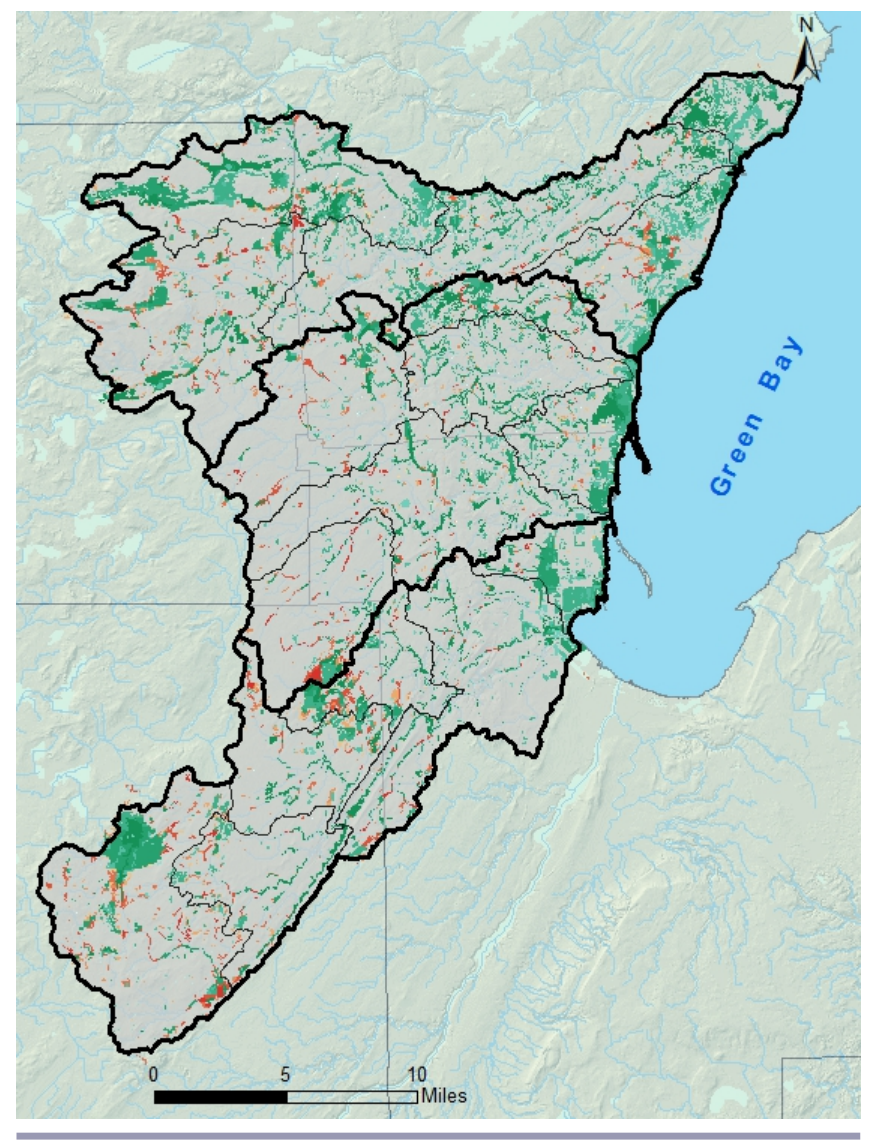

\section{Addressing novel ecosystems}

All restoration sites are novel in that they have conditions and species unlike historical ecosystems. At one end of a restoration site-condition spectrum (Zedler 1999) are ecosystems with only mild impairments, e.g., a shrub-invaded savanna that might be restored using controlled burning. At the other end are mine tailings, which led Bradshaw (1983, 1987) to ask how ecological theory could help land managers to reassemble ecosystems, thereby initiating the field of restoration ecology. Mine tailings not only lack their historical vegetation and soils, but their substrates become toxic when long-buried materials are exposed to the air, e.g., sulfates convert to sulfuric acid. Today's restorationists need to consider the unique combination of stressors and opportunities in each highly degraded site, aim high, test to identify feasible objectives, then adapt objectives and assessments accordingly.

If not restoration to a former state, then what? We recommend that planners first identify severe constraints, then identify a range of goals, from simply vegetated, to intermediate states populated by native plants and animals, to fully restored biota and abiotic conditions. The outcome will likely be a novel ecosystem, perhaps similar to a reference ecosystem, but with fewer species in new combinations and with fewer services than occurred historically. Some might conclude that such an approach opens the door for too wide a range of novel targets, but we suggest working toward the objective of retaining selected attributes of the historical condition. Seastedt et al. (2008) suggested that managers aim to maximize diversity of genotypes, species, and ecosystem functions. Subsequently, Hobbs et al. (2011) and Bullock et al. (2011) suggested intervening to maintain or repair ecosystems and ecosystem services, including the conservation of biodiversity. Policy for adaptive restoration would embrace those targets as ideals, without expecting to hit the bull's-eye. Then, through the structured, experiment-based approach of adaptive restoration, practitioners could rule out unachievable targets and accept lesser outcomes (Table 1).

Phased field research led the FWS to judge the reintroduction of an endangered plant to be in compliance with mitigation requirements at Sweetwater Marsh (Box 2). The first attempt to re-establish salt marsh bird's beak (Cordylanthus maritimus ssp. maritimus) occurred in a site that lacked sufficient pollinators, so researchers shifted to an area with suitable pollinator nesting habitat, which allowed the plants to reproduce as required. Also, FWS judged that nesting habitat for the endangered light-footed clapper rail (Rallus longirostris levipes) was unachievable because experiments explained why the site could not produce the tall cordgrass that the endangered bird prefers for nesting. Policy that calls for an adaptive restoration framework can save time and money by allowing restorationists to redirect efforts to achieve specific objectives in more suitable sites.

Box 2: Sweetwater Marsh on San Diego Bay, a highly degraded site that met two of three restoration goals.

In 1984, CalTrans widened USA Freeway 5, causing impacts to habitat for three species protected by the U.S. Endangered Species Act: the California least tern (Sterna antillarum browni), a migratory bird that forages for small fish in estuarine channels; salt marsh bird's beak, an annual plant that parasitizes perennial, high-marsh plants; and light-footed clapper rail, a resident salt marsh bird. Compensatory mitigation began in 1984, and monitoring and research were added 
after a 1988 lawsuit led to further work. This urban/industrial site is highly degraded, with remnant and excavated marshes, landfills, port facilities, an abandoned railroad, and an armored flood control channel (Fig. 4). Sandy dredge spoils from the bay's shipping channel were excavated to create channels for tern foraging and intertidal marsh for clapper rail nesting habitat. The Pacific Estuarine Research Lab (PERL) provided data to the FWS to judge compliance. Requirements for tern foraging were met in the first three years of assessment (Williams and Zedler 1999), and salt marsh bird's beak was re-established in the second effort, after experimentation indicated pollinator limitation and the need for adjacent upland to support ground-nesting bees (Parsons and Zedler 1997).

For the clapper rail, FWS required seven potential home ranges but did not require that rails occupy them. FWS set eight objectives for each potential home range, two for the high-tide refuge, two for the mid-marsh feeding territory, and four for the low-marsh nesting area (Fig. 5, left). Each objective had to meet a specific standard for three consecutive years. A critical criterion was that tall cordgrass (Spartina foliosa) canopies had to be self-sustaining, i.e., not dependent on fertilizer application.

Requirements for light-footed clapper rail were not met. Field experiments showed that nitrogen addition increased cordgrass height, but sandy dredge spoil was too leaky for nitrogen to accumulate; as soon as fertilization ceased, the cordgrass canopy became short (Lindig-Cisneros et al. 2003). Peer-reviewed publications from PERL documented the pattern of short cordgrass and the cause, which helped FWS judge that clapper rail home ranges were unachievable at this site. FWS established a penalty instead, namely, to remove fill from a nearby remnant salt marsh where fine soils could support tall cordgrass.

Initial policy had the foresight to require a scientific basis for judging outcomes: achievement standards (levels for each attribute) were specified, tall cordgrass had to be self-sustaining, and assessments had to be reported in detail. Also, there was no mandate to keep findings confidential. Three shortcomings of initial policy became obvious during the 10-yr assessment program: sampling methods were not specified, there was no framework for adaptive restoration, and the assessment period was only $3 \mathrm{yr}$, with project proponents deciding when to start the clock. PERL corrected the first two shortcomings by proposing both ground and remote sensing methods for approval by project proponents and FWS. Thereafter, the need for continual evaluation of results and decision making by FWS led to adaptive restoration. PERL initiated annual meetings, presented assessment data, made recommendations, and facilitated agreement on next steps, including experiments to test cause-effect relationships. Field experiments indicated how to meet the criteria and when new efforts were needed.

\section{Adapting to declining biodiversity}

When landscapes lose biodiversity, ecosystems experience functional losses, if not in ecosystem services, then at least in resilience, i.e., the ability to recover from perturbations (Millennium Ecosystem Assessment 2005). There are many examples in coastal California, where $<10 \%$ of historical wetland area remains, and all remaining sites are degraded. The endangered salt marsh bird's beak (Box 2) and a rare succulent, annual pickleweed (Salicornia bigelovii), both colonize bare space and help stabilize soil, but both are annual plants, so their seeds must be available when and where there are canopy openings. Dispersal appears to be limiting; only one-quarter of southern California's 24 salt marshes sustain populations of these species.

Fig. 4. Aerial photo of Sweetwater Marsh National Wildlife Refuge, surrounded by dredge spoils, abandoned railroad track, interstate freeway, and urban and industrial developments. Map: http://maps.google.com/? $\underline{\mathrm{s} l l=32.64028,-117.11028 \& \mathrm{spn}=0.05,0.05}$.

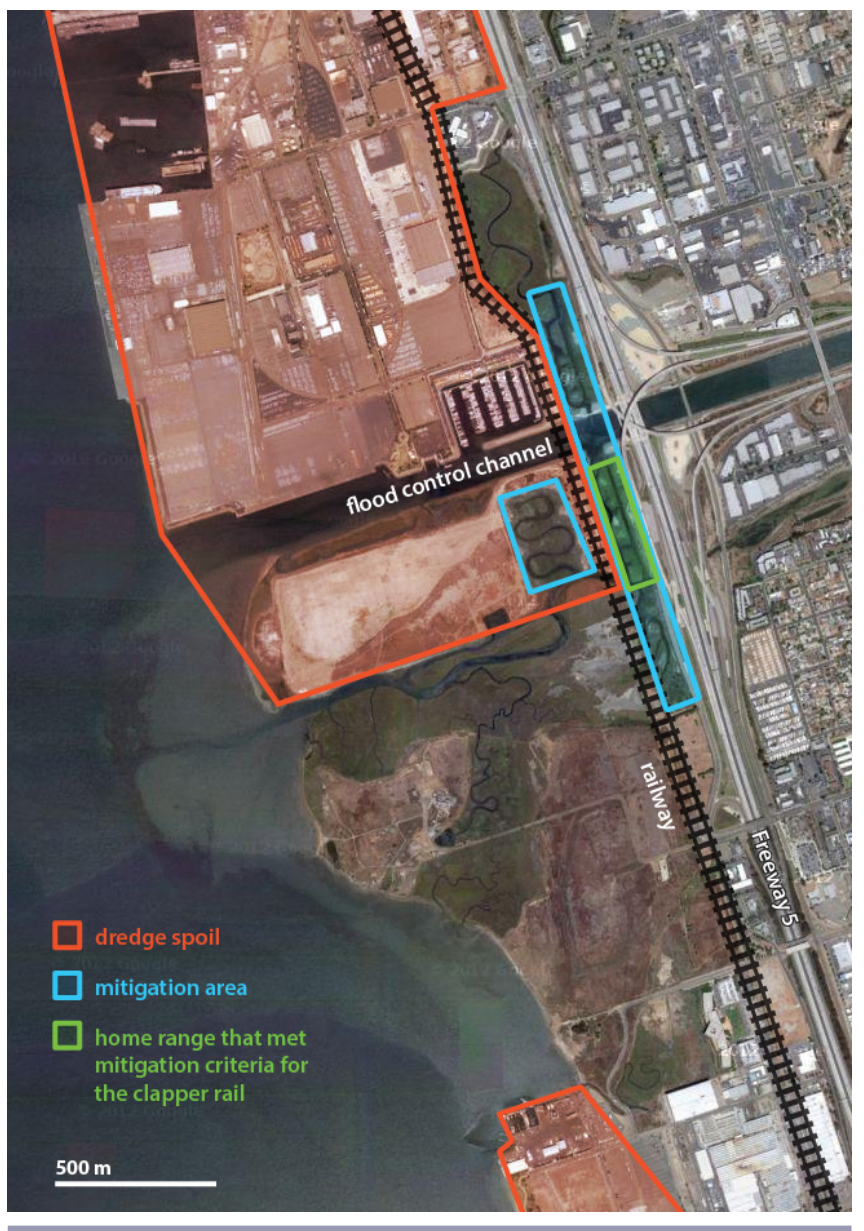

Policy for managing ecosystems with declining diversity should call for retaining and restoring the necessary habitats and species in four key areas: in sites where they occurred historically, in sites where they did not occur historically but are likely to be achievable, in sites that are near remnant populations, and in sites that are in close proximity to one another (Table 1). 
Fig. 5. Eight criteria required to be met for three consecutive years within seven home ranges intended for nesting by the light-footed clapper rail, a U.S. federally endangered species. Monitoring of specific objectives in low, middle, and high marsh habitats at Sweetwater Marsh, California, showed that several criteria were met (shaded cells), but critical criteria were unmet in 1996 and 1997, notably tall cordgrass for nest construction and camouflage (black cells).

Age in 1997 (years)

High Marsh
Mid Marsh
Low Marsh
nesting patch
(cordgrass)

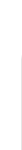

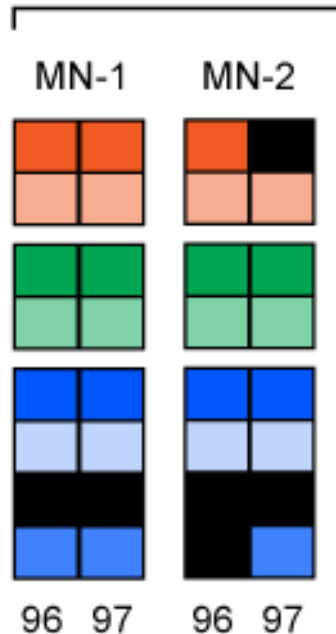

Census Year

\begin{abstract}
$15 \%$ of area $10 \%$ exotics
\end{abstract} $70 \%$ cover $75 \%$ species $15 \%$ of area $50 \%$ cover $\geq 60 \mathrm{~cm} \mathrm{ht}$. $\geq 90 \%$ cover
8
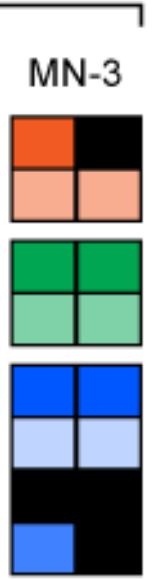

9697
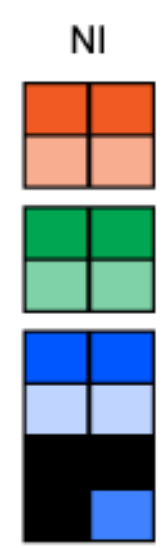

9697
13
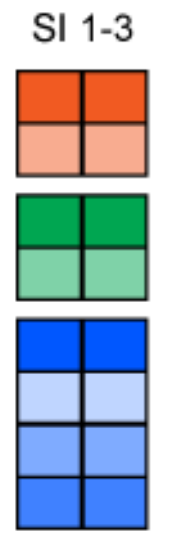

$96 \quad 97$
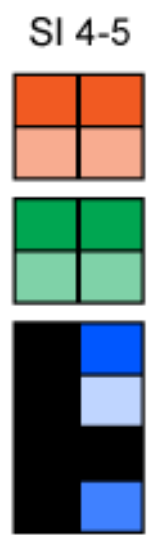

9697
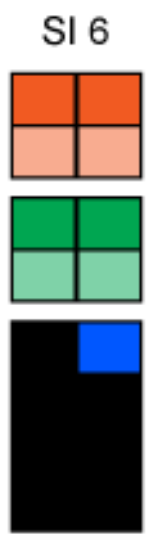

9697
Policy should also discourage the establishment of monotype dominants and call for the initial planting of matrix dominants (Frieswyk et al. 2007), which can cover sites while allowing other native plants to co-exist. Where diverse vegetation is neither easy nor cheap to establish, it is tempting to focus on a single aggressive dominant, e.g., pickleweed in California salt marshes, and Canada bluejoint (Calamagrostis canadensis) in Wisconsin wet meadows. Both could quickly cover bare substrates, but since they are strong monotype dominants, each would reduce opportunities to achieve diverse vegetation. Two common matrix dominants that can cover bare ground quickly without precluding other species from occurring are salt marsh daisy (Jaumea carnosa) in the salt marsh (Bonin and Zedler 2008) and tussock sedge (Carex stricta) in Midwestern wet meadows (Frieswyk et al. 2007). Once matrix species are well established, additional species can be added in phased experimental plantings.

Concern for the declining genetic diversity of rare species raises a debate: Should conservationists preserve locally adapted genotypes and collect narrowly for purposes of reintroduction or should they collect broadly to ensure that a population can re-establish from among the genes introduced from multiple donor populations? Vander Mijnsbrugge et al. (2011) recommend that the domain for seed collections would depend on the restoration goals, with reintroductions of rare species coming from local sources, and reintroductions of more common species into more disturbed sites coming from areas of similar environmental conditions within the region. At Sweetwater Marsh, FWS agreed that propagules of the endangered salt marsh bird's beak should come from the nearest population, Tijuana Estuary, which had about 15 subpopulations of the species. Indeed, the reintroduced population proved to be no less diverse than the donor population (Helenurm and Parsons 1997).

\section{ASSESSING PROGRESS IN CHANGING LANDSCAPES}

Before restoration begins, proponents need to make a longterm commitment, not just a one-time effort. One of the oldest restoration projects began in 1934 at the University of Wisconsin-Madison Arboretum (Fig. 1, Box 3). Efforts continue $78 \mathrm{yr}$ later in response to new stressors, notably urban runoff and invasive plants. Although policy calls for urban runoff to be diverted around the Arboretum, this is unrealistic for a 486-ha site in the lowest-lying landscape position. To satisfy state regulations, $\sim 7$ ha of Arboretum land are being converted to stormwater retention ponds, and the surrounding berms require continual weed control. Long-term adaptive approaches are needed for highly degraded sites to achieve desired targets; this requires long-term assessment and objective judgments of progress.

Box 3: A 78-year-old prairie restoration responds to landscape change.

The University of Wisconsin-Madison Arboretum dates to 1934, when rural land was dedicated to restoring examples of Wisconsin plant communities. Restoration of a formerly cultivated horse pasture 
to tallgrass prairie began with experimental plantings using seed, prairie hay, and imported sod. In 1940-1955, additional plantings and experimental burning increased native plant diversity (Curtis and Partch 1948, Cochrane et al. 2006). Controlled burning was an early response to landscape change; it countered fire suppression in the surrounding rural/urban area. In 1962, the prairie supported $>150$ species and was named after John Curtis. As urban areas and their impervious surfaces expanded, less rainfall infiltrated and more stormwater flowed into Curtis Prairie (Fig. 1). Five vegetation surveys between 1951 and 1976 showed that low areas receiving urban runoff contained weeds and wet prairie species (Blewett and Cottam 1984). To confine inflows, managers excavated a stormwater pond near the inflow in 1969; subsequently, the outflow eroded a small stream. Alongside the stream, a subsurface clay layer impounded stormwater over $\sim 0.4$ ha (Stiles et al. 2008), where reed canary grass (Phalaris arundinacea) became dominant. Currently, the 29-ha Curtis Prairie has a 0.4-ha retention pond, a stream, and $\sim 7$ ha of wetland (Fig. 6).

In 2011, herbaceous wetland habitat in Curtis Prairie supported 37 native species; two (tussock sedge and Canada bluejoint) had the highest frequency of occurrence and shoot biomass. However, the wetland averaged only $4.8 \pm 2.7 \mathrm{species} / \mathrm{m}^{2}$, which was similar to other wetlands with hydrological disturbance and reed canary grass invasions (Kercher et al. 2004). The third most abundant species in Curtis Prairie wetland was reed canary grass. This invasive species responds strongly to ample nitrogen and standing water, displaces native species, and is difficult to eradicate (Green and Galatowitsch 2002, Kercher et al. 2007, Healy and Zedler 2010).

Historical conditions are not restorable. Impervious infrastructure (roofs, roads, etc.) upstream of Curtis Prairie (Fig. 1, right) cannot be reversed, and nutrient-rich stormwater inflows will continue in perpetuity, even if upstream neighbors install shallow depressions to capture runoff at the source (that is, roofs, sidewalks, driveways; often called rain gardens) and use less fertilizer. Addressing landscape change involves accepting wetter conditions and acknowledging that the site is a prairie-wetland mosaic. The Arboretum could continue to aim for high native plant diversity, which is valued for research, education, recreation, and aesthetic appeal. Compositional data suggest that a more diverse sedge meadow is a feasible restoration target for the $\sim 7$-ha wetland. Achieving this new target would require controlling reed canary grass and any future invaders, plus adding species to aim for 16 species/ $\mathrm{m}^{2}$, the average for local native reference sites (Kercher et al. 2004).

The challenge to achieving a diverse sedge meadow is nitrogen enrichment, which increases the abundance of invaders that displace natives (Kercher et al. 2007, Davidson et al. 2012). In Wisconsin, stormwater regulators typically aim to control suspended solids and particulate phosphorus $(\mathrm{P})$ using retention ponds. Retention ponds settle sediment and attached $\mathrm{P}$ but do not remove enough nitrogen (N) to protect wetlands downstream. A shallow, vegetated pond would promote denitrification of dissolved N (Hansson et al. 2005, Collins et al. 2010). The retention pond in Curtis Prairie could be managed as a deep marsh with emergent vegetation and ample roots to facilitate denitrification. To do so would require a policy shift away from deep ponds to trap $\mathrm{P}$ or a regulatory variance for this specific site. This, too, would accommodate landscape change.
Fig. 6. Aerial photo showing the stormwater pond and a $2000 \mathrm{~m}^{2}$ patch of invasive reed canary grass downstream of the pond outflow, within vegetation that was burned in central Curtis Prairie, University of Wisconsin-Madison Arboretum. Photo: J. B. Zedler.

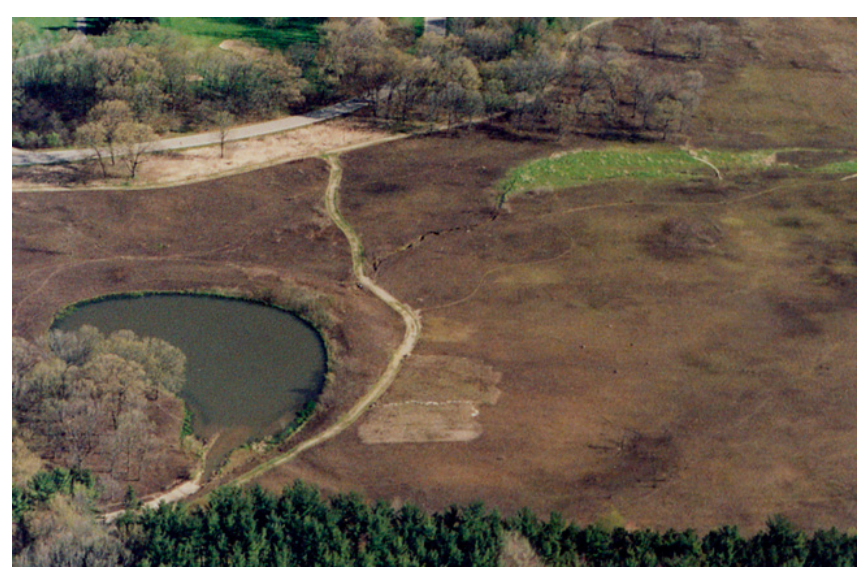

Project proponents such as funding sources, stakeholders, and practitioners all feel the need to claim that their restoration efforts are successful, although success is rarely defined and failure is rarely mentioned (Zedler 2007). Not surprisingly, a meta-analysis of 240 restoration outcomes based on authors' opinions concluded that restoration is rapid and relatively easy, even though almost half of the ecosystems and response variables had not recovered within the study periods (Jones and Schmitz 2009). A later meta-analysis of 621 restored wetlands found instead that "recovery of wetlands following restoration as currently practiced is often slow and incomplete," based on data showing that restored sites averaged $26 \%$ lower in structural attributes, especially plant communities, and $23 \%$ lower in functional attributes, especially soil carbon storage (Moreno-Mateos et al. 2012:6).

Restoration policy should call for clarity in assessing progress based on quantitative data and objectivity in judging outcomes. As historical targets become increasingly difficult to achieve and restoration funding becomes scarcer, restorationists can still describe degrees of progress, highlighting targets that were met and the proportion of each objective that is still being pursued. The public can thus continue to champion efforts to sustain biodiversity and ecosystem services.

In the adaptive restoration framework, even an unmet objective represents progress because it triggers a forward step, namely, shifting resources toward more promising approaches. At Tijuana Estuary, a field experiment demonstrated that costly planting of pickleweed as vegetative propagules was not necessary. This widespread species 
establishes readily on bare mud during winter dispersal of seeds (Lindig-Cisneros and Zedler 2002). In a more complicated example (Box 2), a 5-yr experiment showed that nitrogen addition could not provide the required selfsustaining canopy of tall cordgrass (Lindig-Cisneros et al. 2003). Without the science, futile efforts would have continued indefinitely.

Policy should call for restoration progress to be assessed over time frames that are suitable for assessing self-sustainability. Long-term management is essential, probably for longer than the $25 \mathrm{yr}$ suggested by Tischew et al. (2010) for wetland mitigation sites, with funds set aside for weed control, prescribed burning, replanting, and other aspects of adaptive restoration. At Sweetwater Marsh (Box 2), the seeded bird's beak population was required to be monitored for just three years, during which the population expanded, and there was no specification that the population be self-sustaining. In the fourth year, it crashed (Zedler 1998), but was not extirpated (J. B. Zedler, personal observation). A science-based policy for mitigation requirements under the U.S. Endangered Species Act would withhold judgment until research shows why a population is or is not sustainable. It would then be clearer where to continue efforts to comply with mitigation requirements.

If a project falls short of expectations, it is tempting to conclude that it will eventually achieve its target if it is on the right trajectory. However, multiple attributes will not necessarily follow the same path (Zedler and Callaway 1999). It must be clear whether all stated criteria must be met for a project to comply with requirements. Although there was great political pressure to certify the clapper rail habitat restoration as compliant because most of the eight criteria were met on most of the seven proposed home ranges (Box 2), FWS requirements were clear that all eight criteria had to be met on all seven home ranges, and tall cordgrass had to be selfsustaining, i.e., not dependent on nitrogen addition.

Adaptive restoration is open-ended, continues indefinitely, and does not guarantee eventual self-sustainability. An ecosystem with a long-lived dominant might not reach maturity for a century. For example, longleaf pine (Pinus palustris) lives up to $300 \mathrm{yr}$ in Georgia's wet savannas. In a long-term adaptive approach, Kirkman et al. (2007) learned to suppress fire for $\sim 10 \mathrm{yr}$ while longleaf pine seedlings establish and to conduct burning thereafter to sustain a diverse understory in a rural landscape that lacks wildfires. Likewise, Curtis Prairie (Box 3) will always need controlled burning in its urban landscape, which also lacks wildfires.

Long-term assessment allows researchers to determine where and how the ability to sustain restored ecosystems and their services are constrained by landscape changes at global, watershed, site, and species scales. Science-based data facilitate objective judgments of progress. Through adaptive restoration, practitioners can adapt goals and efforts to landscape change.

\section{CONCLUSION}

In the face of landscape changes at multiple scales, we recommend policy for setting restoration objectives and assessing outcomes within long-term adaptive restoration programs. Restorationists could then meet the challenges of altered conditions of our globe, watersheds, sites, and species. Policy would direct planners to be forward-thinking, able to identify constraints at multiple spatial scales, able to set targets that are potentially achievable, required to recognize when targets cannot be met, and able to adapt to landscape change. Adaptive restoration combines learning and restoring. First, planners set multiple, clear objectives. They propose alternative methods to achieve each target, then implement field experiments on-site and use specific standards to assess outcomes objectively. Experimentation allows project personnel to determine why key objectives were not achieved on schedule. Objectives that are judged unachievable are set aside, and alternative targets are explored and selected. Results are presented as degrees of progress, based on data, not subjective opinion.

Responses to this article can be read online at: http://www.ecologyandsociety.org/issues/responses. $\mathrm{php} / 5197$

\section{Acknowledgments:}

We thank EPA Great Lakes Restoration Initiative (GLOOE067-0) and Earth Island Institute for funding research and the Joyce Foundation for funding watershed planning. We thank our research team (S. Loheide, A. Thompson, J. Miller, S. Prellwitz) and collaborators at Wisconsin Department of Natural Resources, The Nature Conservancy, and Environmental Law Institute (T. Bernthal, J. Wagner, M. Grimm, G. Casper, J. Kline, and J. Wilkinson).

\section{LITERATURE CITED}

Adamus, P. R., L. T. Stockwell, E. J. Clairain, Jr., M. E. Morrow, L. P. Rozas, and D. R. Smith. 1991. Wetland evaluation technique (WET): volume I: literature review and evaluation rationale. Technical Report WRP-DE-2. U.S. Army Corps of Engineers, Vicksburg, Mississippi, USA. [online] URL: http://www.dtic.mil/cgi-bin/GetTRDoc?Location= U2\&doc=GetTRDoc.pdf\&AD=ADA251739.

Aradóttir, A. L. 2007. Restoration of birch and willow woodland on eroded areas. Pages 67-74 in G. Halldorsson, E. S. Oddsdottir, and O. Eggertsson, editors. Effects of afforestation on ecosystems, landscape and rural 
development: proceedings of the AFFORNORD conference, Reykholt, Iceland, June 18"22, 2005. Nordic Council of Ministers, Copenhagen, Denmark. [online] URL: http:// eprints.ulster.ac.uk/14798/1/AFFORNORD_Conference.pdf.

Arheimer, B., G. Torstensson, and H. B. Wittgren. 2004. Landscape planning to reduce coastal eutrophication: agricultural practices and constructed wetlands. Landscape and Urban Planning 67(1-4):205-215. http://dx.doi. org/10.1016/S0169-2046(03)00040-9

Arnalds, O. 2010. Dust sources and deposition of aeolian materials in Iceland. Icelandic Agricultural Sciences 23:3-21.

Aronson, J., J. N. Blignaut, S. J. Milton, D. Le Maitre, K. J. Esler, A. Limouzin C. Fontaine, M. P. De Wit, W. Mugido, P. Prinsloo, L. Van Der Elst, and N. Lederer. 2010. Are socioeconomic benefits of restoration adequately quantified? A meta-analysis of recent papers (2000-2008) in Restoration Ecology and 12 other scientific journals. Restoration Ecology 18(2):143-154. http://dx.doi.org/10.1111/j.1526-100X.2009.00638. $\underline{\mathrm{X}}$

Blewett, T. J., and G. Cottam. 1984. History of the University of Wisconsin Arboretum prairies. Transactions of the Wisconsin Academy of Science, Arts, and Letters 72:130-144.

Bobbink, R., K. Hicks, J. Galloway, T. Spranger, R. Alkemade, M. Ashmore, M. Bustamante, S. Cinderby, E. Davidson, F. Dentener, B. Emmett, J.-W. Erisman, M. Fenn, F. Gilliam, A. Nordin, L. Pardo, and W. De Vries. 2010. Global assessment of nitrogen deposition effects on terrestrial plant diversity: a synthesis. Ecological Applications 20(1):30-59. http://dx.doi.org/10.1890/08-1140.1

Bonin, C. L., and J. B. Zedler. 2008. Southern California salt marsh dominance relates to plant traits and plasticity. Estuaries and Coasts 31(4):682-693. http://dx.doi.org/10.1007/ $\underline{\mathrm{s} 12237-008-9057-4}$

Bradshaw, A. D. 1983. The reconstruction of ecosystems: presidential address to the British Ecological Society, December 1982. Journal of Applied Ecology 20(1):1-17. http://dx.doi.org/10.2307/2403372

Bradshaw, A. D. 1987. Restoration, the acid test of ecology. Pages 23-29 in W. R. Jordan III, M. E. Gilpin, and J. D. Aber, editors. Restoration ecology: a synthetic approach to ecological research. Cambridge University Press, Cambridge, UK.

Brinson, M. M. 1993. A hydrogeomorphic classification for wetlands. Technical Report WRP-DE-4. U.S. Army Corps of Engineers, Washington, D.C., USA. [online] URL: http://el. erdc.usace.army.mil/wetlands/pdfs/wrpde4.pdf.

Bullock, J. M., J. Aronson, A. C. Newton, R. F. Pywell, and J. M. Rey-Benayas. 2011. Restoration of ecosystem services and biodiversity: conflicts and opportunities. Trends in
Ecology and Evolution 26(10):541-549. http://dx.doi. org/10.1016/j.tree.2011.06.011

Choi, Y. D. 2004. Theories for ecological restoration in changing environment: toward 'futuristic' restoration. Ecological Research 19(1):75-81. http://dx.doi.org/10.1111/ j.1440-1703.2003.00594.x

Choi, Y. D. 2007. Restoration ecology to the future: a call for new paradigm. Restoration Ecology 15(2):351-353. http://dx. doi.org/10.1111/j.1526-100X.2007.00224.X

Cochrane, T. S., K. Elliot, and C. S. Lipke. 2006. Prairie plants of the University of Wisconsin-Madison Arboretum. University of Wisconsin Press, Madison, Wisconsin, USA.

Collins, K. A., T. J. Lawrence, E. K. Stander, R. J. Jontos, S. S. Kaushal, T. A. Newcomer, N. B. Grimm, and M. L. Cole Ekberg. 2010. Opportunities and challenges for managing nitrogen in urban stormwater: a review and synthesis. Ecological Engineering 36(11):1507-1519. http://dx.doi. org/10.1016/j.ecoleng.2010.03.015

Conservation Foundation. 1988. Protecting America's wetlands: an action agenda: the final report of the National Wetlands Policy Forum. Conservation Foundation, Washington, D.C., USA.

Curtis, J. T., and M. L. Partch. 1948. Effect of fire on the competition between blue grass and certain prairie plants. American Midland Naturalist 39(2):437-443. http://dx.doi. org/10.2307/2421594

Davidson, E. A., M. B. David, J. N. Galloway, C. L. Goodale, R. Haeuber, J. A. Harrison, R. W. Howarth, D. B. Jaynes, R. R. Lowrance, B. T. Nolan, J. L. Peel, R. W. Pinder, E. Porter, C. S. Snyder, A. R. Townsend, and M. H. Ward. 2012. Excess nitrogen in the U.S. environment: trends, risks, and solutions. Issues in Ecology Report 15. Ecological Society of America, Washington, D.C., USA. [online] URL: http://www.esa.org/ science_resources/issues/FileEnglish/issuesinecology15.pdf.

Doherty, J. M., J. C. Callaway, and J. B. Zedler. 2011. Diversity-function relationships changed in a long-term restoration experiment. Ecological Applications 21 (6):2143-2155. http://dx.doi.org/10.1890/10-1534.1

Drexler, J. Z., and B. L. Bedford. 2002. Pathways of nutrient loading and impacts on plant diversity in a New York peatland. Wetlands 22(2):263-281. http://dx.doi.org/10.1672/0277-5212 (2002)022[0263:PONLAI]2.0.CO;2

Fox, L., I. Valiela, and E. L. Kinney. 2012. Vegetation cover and elevation in long-term experimental nutrient-enrichment plots in Great Sippewissett Salt Marsh, Cape Cod, Massachusetts: implications for eutrophication and sea level rise. Estuaries and Coasts 35(2):445-458. http://dx.doi. org/10.1007/s12237-012-9479-x 
Frieswyk, C. B., C. Johnston, and J. B. Zedler. 2007. Identifying and characterizing dominant plants as an indicator of community condition. Journal of Great Lakes Research 33 (S3):S125-S135. http://dx.doi.org/10.3394/0380-1330(2007) 33[125:IACDPA]2.0.CO;2

Galloway, J. N., A. R. Townsend, J. W. Erisman, M. Bekunda, Z. Cai, J. R. Freney, L. A. Martinelli, S. P. Seitzinger, and M. A. Sutton. 2008. Transformation of the nitrogen cycle: recent trends, questions, and potential solutions. Science 320:889-892. http://dx.doi.org/10.1126/science.1136674

Green, E. K., and S. M. Galatowitsch. 2002. Effects of Phalaris arundinacea and nitrate- $\mathrm{N}$ addition on the establishment of wetland plant communities. Journal of Applied Ecology39(1):134-144. http://dx.doi.org/10.1046/ j.1365-2664.2002.00702.x

Grubb, P. J. 1977. The maintenance of species-richness in plant communities: the importance of the regeneration niche. Biological Reviews 52(1):107-145. http://dx.doi.org/10.1111/ j.1469-185X.1977.tb01347.x

Halldórsson, G., A. L. Aradóttir, O. Arnalds, and K. Svarvarsdóttir. 2011. Restoration in Iceland. Pages 9-12 in A. L. Aradóttir and G. Halldórsson, editors. Vistheimt á Íslandi. Landbúnaôarháskóli slands og Landgraeôsla rikisins, Reykjavik, Iceland.

Hansson, L.-A., C. Brönmark, P. A. Nilsson, and K. Åbjörnsson. 2005. Conflicting demands on wetland ecosystem services: nutrient retention, biodiversity or both? Freshwater Biology 50(4):705-714. http://dx.doi.org/10.1111/ j.1365-2427.2005.01352.x

Harris, J. A., R. J. Hobbs, E. Higgs, and J. Aronson. 2006. Ecological restoration and global climate change. Restoration Ecology 14(2):170-176. http://dx.doi.org/10.1111/ j.1526-100X.2006.00136.X

Healy, M. T., and J. B. Zedler. 2010. Set-backs in replacing Phalaris arundinacea monotypes with sedge meadow vegetation. Restoration Ecology 18(2):155-164. http://dx.doi. org/10.1111/j.1526-100X.2009.00645.X

Helsinki Commission. 2003. The Baltic Sea joint comprehensive environmental action programme (JCP): ten years of implementation. Baltic Sea Environment Proceedings 88. Helsinki Commission, Helsinki, Finland. [online] URL: http://www.helcom.fi/stc/files/Publications/Proceedings/bsep88. pdf.

Helenurm, K., and L. S. Parsons. 1997. Genetic variation and the reintroduction of Cordylanthus maritimus ssp. maritimus to Sweetwater Marsh, California. Restoration Ecology 5 (3):236-244. http://dx.doi.org/10.1046/j.1526-100X.1997.09728.
Hobbs, R. J., L. M. Hallett, P. R. Ehrlich, and H. A. Mooney. 2011. Intervention ecology: applying ecological science in the twenty-first century. BioScience 61(6):442-450. http://dx.doi. org/10.1525/bio.2011.61.6.6

Jones, H. P., and O. J. Schmitz. 2009. Rapid recovery of damaged ecosystems. PLoS One 4(5): e5653. http://dx.doi. org/10.1371/journal.pone.0005653

Jordan, S. J., J. Stoffer, and J. A. Nestlerode. 2011. Wetlands as sinks for reactive nitrogen at continental and global scales: a meta-analysis. Ecosystems 14(1):144-155. http://dx.doi. org/10.1007/s10021-010-9400-z

Kercher, S. M., Q. J. Carpenter, and J. B. Zedler. 2004. Interrelationships of hydrologic disturbances, reed canary grass (Phalaris arundinacea L.), and native plants in Wisconsin wet meadows. Natural Areas Journal 24 (4):316-325.

Kercher, S. M., A. Herr-Turoff, and J. B. Zedler. 2007. Understanding invasion as a process: the case of Phalaris arundinacea in wet prairies. Biological Invasions 9 (6):657-665. http://dx.doi.org/10.1007/s10530-006-9066-9

Kirkman, L. K., R. J. Mitchell, M. J. Kaeser, S. D. Pecot, and K. L. Coffey. 2007. The perpetual forest: using undesirable species to bridge restoration. Journal of Applied Ecology 44 (3):604-614. http://dx.doi.org/10.1111/j.1365-2664.2007.01310. $\underline{\mathrm{X}}$

Kline, J., T. Bernthal, M. Burzynski, and K. Barrett. 2006. Milwaukee river basin wetland assessment project: developing decision support tools for effective planning. Final Report to U.S. EPA, Region V. Wisconsin Department of Natural Resources, Madison, Wisconsin. [online] URL: http:// dnr.wi.gov/topic/wetlands/documents/Mukwonago_VersionMRPWAP August 17.pdf.

Larkin, D. J., S. P. Madon, J. M. West, and J. B. Zedler. 2008. Topographic heterogeneity influences fish use of an experimentally restored tidal marsh. Ecological Applications 18(2):483-496. http://dx.doi.org/10.1890/06-1984.1

Larkin, D. J., J. M. West, and J. B. Zedler. 2009. Created pools and food availability for fishes in a restored salt marsh. Ecological Engineering 35(1):65-74. http://dx.doi.org/10.1016/ j.ecoleng.2008.09.009

Lindig-Cisneros, R., and J. B. Zedler. 2002. Halophyte recruitment in a salt marsh restoration site. Estuaries 25 (6):1174-1183. http://dx.doi.org/10.1007/BF02692214

Lindig-Cisneros, R., J. Desmond, K. E. Boyer, and J. B. Zedler. 2003. Wetland restoration thresholds: can a degradation transition be reversed with increased effort? Ecological 
Applications 13(1):193-205. http://dx.doi.org/10.1890/1051-0761 (2003)013[0193:WRTCAD]2.0.CO;2

Millennium Ecosystem Assessment. 2005. Ecosystems and human well being: wetlands and water: synthesis. World Resources Institute, Washington, D.C., USA. [online] URL: http://www.millenniumassessment.org/documents/document.358. aspx.pdf.

Miller, N., T. Bernthal, J. Wagner, M. Grimm, G. Casper, and J. Kline. 2012. The Duck-Pensaukee watershed approach: mapping wetland services, meeting watershed needs. The Nature Conservancy, Madison, Wisconsin, USA. [online] URL: http://conserveonline.org/library/the-duck-pensaukeewatershed-approach-mapping.

Moreno-Mateos, D., M. E. Power, F. A. Comín, and R. Yockteng. 2012. Structural and functional loss in restored wetland ecosystems. PLoS Biology 10: e1001247. http://dx. doi.org/10.1371/journal.pbio.1001247

National Research Council Committee on Wetland Mitigation. 2001. Compensating for wetland losses under the Clean Water Act. National Academy Press, Washington, D. C., USA.

Parsons, L. S., and J. B. Zedler. 1997. Factors affecting reestablishment of an endangered annual plant at a California salt marsh. Ecological Applications 7(1):253-267. http://dx. doi.org/10.1890/1051-0761(1997)007[0253:FAROAE]2.0.CO;2

Pickett, S. T. A., and V. T. Parker. 1994. Avoiding the old pitfalls: opportunities in a new discipline. Restoration Ecology 2(2):75-79. http://dx.doi.org/10.1111/j.1526-100X.1994.tb00044. $\underline{\mathrm{X}}$

Prospero, J. M., J. E. Bullard, and R. Hodgkins. 2012. Highlatitude dust over the North Atlantic: inputs from Icelandic proglacial dust storms. Science 334(6072):1078-1082. http:// dx.doi.org/10.1126/science.1217447

Rey Benayas, J. M., A. C. Newton, A. Diaz, and J. M. Bullock. 2009. Enhancement of biodiversity and ecosystem services by ecological restoration: a meta-analysis. Science 325 (5944):1121-1124. http://dx.doi.org/10.1126/science.1172460

Schmitt, R. J., and C. W. Osenberg, editors. 1996. Detecting ecological impacts: concepts and applications in coastal habitats. Academic Press, San Diego, California, USA.

Schuerch, M., J. Rapaglia, V. Liebetrau, A. Vafeidis, and K. Reise. 2012. Salt marsh accretion and storm tide variation: an example from a barrier island in the North Sea. Estuaries and Coasts 35(2):486-500. http://dx.doi.org/10.1007/s12237-011-9461$\underline{\mathrm{z}}$

Seastedt, T. R., R. J. Hobbs, and K. N. Suding. 2008. Management of novel ecosystems: are novel approaches required? Frontiers in Ecology and the Environment 6 (10):547-553. http://dx.doi.org/10.1890/070046
Stiles, C. A., B. Bemis, and J. B. Zedler. 2008. Evaluating edaphic conditions favoring reed canary grass invasion in a restored native prairie. Ecological Restoration 26(1):61-70. http://dx.doi.org/10.3368/er.26.1.61

Stohlgren, T. J., P. Pysek, J. Kartesz, M. Nishino, A. Pauchard, M. Winter, J. Pino, D. M. Richardson, J. R. U. Wilson, B. R. Murray, M. L. Phillips, M.-Y. Li, L. Celesti-Grapow, and X. Font. 2011. Widespread plant species: natives versus aliens in our changing world. Biological Invasions 13(9):1931-1944. http://dx.doi.org/10.1007/s10530-011-0024-9

Suding, K. N. 2011. Toward an era of restoration in ecology: successes, failures, and opportunities ahead. Annual Review of Ecology, Evolution and Systematics 42:465-487. http://dx. doi.org/10.1146/annurev-ecolsys-102710-145115

Thiere, G., J. Stadmark, and S. E. B. Weisner. 2011. Nitrogen retention versus methane emission: environmental benefits and risks of large-scale wetland creation. Ecological Engineering 37(1):6-15. http://dx.doi.org/10.1016/j. ecoleng.2009.02.002

Tiner, R. W. 2005. Assessing cumulative loss of wetland functions in the Nanticoke River watershed using enhanced National Wetlands Inventory data. Wetlands 25(2):405-419. http://dx.doi.org/10.1672/15

Tischew, S., A. Baasch, M. K. Conrad, and A. Kirmer. 2010. Evaluating restoration success of frequently implemented compensation measures: results and demands for control procedures. Restoration Ecology 18(4):467-480. http://dx.doi. org/10.1111/j.1526-100X.2008.00462.X

Vander Mijnsbrugge, K., A. Bischoff, and B. Smith. 2010. A question of origin: where and how to collect seed for ecological restoration. Basic and Applied Ecology 11(4):300-311. http:// dx.doi.org/10.1016/j.baae.2009.09.002

Williams, G. D., and J. B. Zedler. 1999. Fish assemblage composition in constructed and natural tidal marshes of San Diego Bay: relative influence of channel morphology and restoration history. Estuaries 22(3):702-716. http://dx.doi. org/10.2307/1353057

Zedler, J. B. 1998. Replacing endangered species habitat: the acid test of wetland ecology. Pages 364-379 in P. L. Fiedler and P. M. Kareiva, editors. Conservation biology: for the coming decade. Second edition. Chapman and Hall, New York, New York, USA.

Zedler, J. B. 1999. The ecological restoration spectrum. Pages 301-318 in W. Streever, editor. An international perspective on wetland rehabilitation. Kluwer Academic Press, Dordrecht, The Netherlands.

Zedler, J. B. 2000. Progress in wetland restoration ecology. Trends in Ecology and Evolution 15(10):402-407. http://dx. doi.org/10.1016/S0169-5347(00)01959-5 
Zedler, J. B. 2003. Wetlands at your service: reducing impacts of agriculture at the watershed scale. Frontiers in Ecology and Environment 1(2):65-72. http://dx.doi.org/10.1890/1540-9295 (2003)001[0065:WAYSRI]2.0.CO;2

Zedler, J. B. 2007. Success: an unclear, subjective descriptor of restoration outcomes. Ecological Restoration 25 (3):162-168. http://dx.doi.org/10.3368/er.25.3.162

Zedler, J. B. 2010a. How frequent storms affect wetland vegetation: a preview of climate-change impacts. Frontiers in Ecology and the Environment 8(10):540-547. http://dx.doi. org/10.1890/090109

Zedler, J. B. 2010b. Wetlands as harbingers of climate change. National Wetlands Newsletter 32(1):13-17.

Zedler, J. B., and J. C. Callaway. 1999. Tracking wetland restoration: do mitigation sites follow desired trajectories? Restoration Ecology 7(1):69-73. http://dx.doi.org/10.1046/ j.1526-100X.1999.07108.X

Zedler, J. B., and J. C. Callaway. 2003. Adaptive restoration: a strategic approach for integrating research into restoration projects. Pages 167-174 in D. J. Rapport, W. L. Lasley, D. E. Rolston, N. O. Nielsen, C. O. Qualset, and A. B. Damania, editors. Managing for healthy ecosystems. Lewis Publishers, Boca Raton, Florida, USA.

Zedler, J. B., and J. M. West. 2008. Declining diversity in natural and restored salt marshes: a 30-year study of Tijuana Estuary. Restoration Ecology 16(2):249-262. http://dx.doi. org/10.1111/j.1526-100X.2007.00268.X 